\title{
THE NEW DIMENSION OF WAR - THE UKRAINE CONFLICT
}

\section{Sylwia DEMEDZIUK}

War Studies University, Warsaw, Poland

sylwiademedziuk@gmail.com

\begin{abstract}
The article focuses on the hybrid conflict on the territory of Ukraine since 2013; its aim is to depict characteristic features of the hybrid war. The background of this article is the politics of Russia towards Ukraine since 1991, when this country gained its independence. In the opinion of Russians, Ukraine is a geopolitical misunderstanding, which openly violates the concept of "Russkiy Mir" (the Russian world). This means that Russia constantly aims at maintaining its sphere of influence in terms of the economy and politics in this region, as well as control over the military potential. Russia's concerns mainly come from Ukraine's desire to participate in some organisations, such as the EU or NATO. A real breakthrough was the Maidan Revolution and the annexation of Crimea, which resulted in the hybrid war in Ukraine.

The analysis of the current source literature lets us draw certain conclusions, namely it gives us the chance to determine that the actions of Russia on the territory of Ukraine are the typical methods of a hybrid war, which is a modern war, whose shape and character are constantly being created and generated by the contemporary researchers of this issue.
\end{abstract}

Key words: Ukraine, geostrategy, new dimension of war, Russia, conflict

\section{Introduction}

Changeability, unpredictability and surprise constitute elementary conditions for the security of every country in the modern international arena. These features result from the dynamics of liability of the interstate situation over the centuries. 
In this article, the author puts the main focus on the changes happening at the turn of the XX and XXI centuries.

An immeasurable metamorphosis of the contemporary world order was the dissolution of the Soviet Union in December, 1991. "The USSR as a subject of

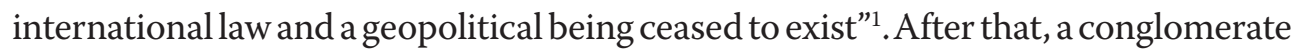
consisting of 15 independent nations was formed. The interests, power and the level of political and economic development of these countries were varied. From a country that extended across 22 million square kilometres and was inhabited by approximately 293 million people, 15 countries with distinct culture, politics and economy emerged. One of these countries was the above-mentioned Ukraine ${ }^{2}$.

The rule of changeability, unpredictability and surprise is not only applied in literature when it comes to describing international relations throughout history, but also issues concerning new military conflicts. With the flow of time, they take a completely new form and structure, which is still an innovative, or even evolutionary area for the development of scientific research.

Touching upon the issue of the conflict in Ukraine, as a new dimension of war, the author deals with a few vital notions, namely: the character of the new dimension of war, the politics of the Russian Federation towards Ukraine, the causes for the conflict in Ukraine and the features of the new war in the Russian-Ukrainian conflict. The last element concerns synthetic conclusions summarising political and military relations between Russia and Ukraine, as well as the results of this conflict influencing the functioning of both countries.

The aim of this article is to depict the Kremlin's methods of conducting a modern war, which is also called a hybrid war. This paper is based on an analysis of the research findings of the authors who examined this subject matter, and also the author's own research concerning Russia's politics towards Ukraine. The time frames were delineated by the author as the period since 1991, which signifies the dissolution of the USSR, regarded as the starting point for the discussed issues, and up to 2016.

1 An entry in the preamble of the Commonwealth of Independent States, a new integration agreement, consociating the majority of states of the former Soviet Union.

2 The Union of Soviet Socialist Republic would be 90. The anniversary of formation, http:// www.newsweek.pl/historia/zwiazek-socjalistycznych-republik-sowieckich-mialby-90-lat-rocznica-utworzenia,100002,1,1.html [06.10.2016]. 


\section{The characteristic of the new dimension of war}

In order to develop the topic of modern war, we should take into consideration the sole notion of war and its attributes. The scientific community of the War Studies University determines war as the socio-political phenomenon present in the history of man since the very beginning of his social recognition, with a range increasing together with the rise of technology. War was a term coined in the XIX and XX centuries and it means: an organised (prepared) form of military conflict between countries, nations, blocks of countries and non-state organisations, as the continuation of politics (ideology, religion) through violence, whose main expression is armed fighting, the goal of which is to gain certain political, economic or ideological (religious) interests. War is defined as a form of a military conflict which, at the same time, is a term with a narrower objective scope, which finds its application in the field of international law"3. A military conflict, apart from war, encompasses an armed intervention, an armed incident, a military coup, a military blockage, the demonstration of power and other things.

In line with the theory of Carl von Clauzewitz, war is distinguished by the very close relationship between politics, nation and war, the priority of politics towards war, and treating war (violence) as a political tool ${ }^{4}$.

According to C. Clausewitz: every era has its wars, which is why war over the last decades (at the turn of the XX and XXI century) has gradually and intangibly changed its character. Alvin and Heidi Toffler write about the dimension of a modern war. This couple examine the aspects of modern war. The main thesis of their publication "War and anti-war" is that there are 3 civilization waves, which relate directly to all three waves of war. The first one mentioned by the authors is the agrarian wave, the second is called industrial and the third - modern (postindustrial). The symbols of each are respectively: a hoe, an assembly belt and a computer, which represent those waves through the image ${ }^{5}$.

3 Stownik terminów z zakresu bezpieczeństwa narodowego, $6^{\text {th }}$ Edition, Warsaw, 2008, p. 158.

4 C. Clauzewitz, O wojnie, Warsaw, 2010.

5 R. Smentek, Alvin and Heidi Toffler: Wojna i antywojna. Jak przetrwać u progu XXI wieku?, http://www.psz.pl/98-ksiazka/alvin-i-heidi-toffler-wojna-i-antywojna-jak-przetrwacu-progu-xxi-wieku [11.01.2017]. 
New wars, the wars of the so called third wave, are the wars of the constantly forming post-Cold-War international order. Let us present some of their characteristic features ${ }^{6}$ :

- the parties of the conflict are non-public actors, paramilitary groups, mercenaries controlled by powers (denationalisation or privatisation of war);

- dissymmetry, which means that the parties of the conflict are not equal;

- it is hard to define the opponent, the aims of the war and determine the beginning and the end of the conflict;

- there are very often cultural, ethic, and religious roots of the conflict;

- strategic places and institutions for the state are to be destroyed, since they are a target;

- the next aim may be the malfunction of an economic situation (short-term) in a particular country, in relation with the above-mentioned actions (e.g. a drop in the values of shares of the listed companies);

- civilians are the main victims;

- unfavourable media propaganda appears that is supposed to worsen the image of a certain country on the international level;

- illegal and harmful activity in cyberspace;

- these are very often wars of internal character, which become international with time;

- the parties of the conflict are financed through organised crime, selling natural resources, and other illegal sources.

The aim of the "new" war is destruction of the opponent, his economic and military potential. by keeping the soldier apart from the factual battlefield ${ }^{7}$. The determinant of the "threshold of war," or the factual start of the warfare is the use of military forces. The hybrid war is a kind of war that begins and finishes just before the above mentioned "threshold of war," which means that military manoeuvres do not occur at all, or, if so, it happens in the latter course of war. The hybridism of war presupposes the coexistence of various of its generations -

6 The conclusions from the analysis of the literature of professor's Bolesław Balcerowicz and the literature from the War Studies University.

7 J. Regina-Zacharski, Wojna na Ukrainie w 2014 roku w świetle wspótczesnych rosyjskich koncepcji polityczno-wojskowych, in: R. Potocki, M. Domagała, D. Miłoszewska (ed.), Czas EuroMajdanu, Warsaw, 2014, p. 143. 
the parties of the conflict, as well as the types of armed hostilities - symmetrical and asymmetrical ones ${ }^{8}$.

These are the reasons why the new dimension of war, which is the war of the "third wave", is hard to prevent, or prepare for. This war is very dynamic, secret, surprising, hard to predict and cease. Examples of the new dimension of war are: the Syrian conflict, the Georgian conflict and the one described in this paper, namely the Russian-Ukrainian conflict.

\section{The politics of the Russian Federation toward Ukraine}

In order to have a full understanding of the actions taken by Russia on Ukrainian territory, one needs to get acquainted with its strategy and geopolitics towards the post-Soviet states from the very beginning of their independent existence.

The Russian Federation, as a successor to the former Soviet Union, is nowadays viewed as a world power in the international arena. At around 17 million square kilometres, Russia is the largest country in the world by surface area, extending across 2 continents -Europe and Asia. It is also one of the most populous countries with around 143.5 million people and a vast potential of energy resources. Russia is one of the world's leading producers of natural gas and oil. It is in third place, after Saudi Arabia and the USA, in the production of oil, and in second place, right behind the USA when it comes to the extraction of gas ${ }^{9}$. Possessing natural resources and the possibility of their extraction and processing puts Russia on a pedestal in the global political arena. Oil, as well as gas and nuclear energy, which Russia also produces, are the key instruments used by this country in international politics.

Ukraine is the second largest country (after Russia), since it has an area of 603,500 square kilometres, and its population is around 45 million. Ukraine is not very

8 J. Czaputowicz, Bezpieczeństwo międzynarodowe. Wspótczesne koncepcje, Warsaw, 2012, pp. 61-62.

9 J.P. Gieorgica, Rosja w Europie i świecie, [in:], A. Dorosz, Z. Olesiński, L. Pastusiak (ed.), Stosunki międzynarodowe. Teoria i praktyka, Warsaw, 2015, pp. 273-274. 
rich in natural resources. The Ukrainian economy is mostly based on agriculture thanks to its fertile soils. The most significant natural resources of Ukraine are iron ore, black coal, manganese ore, and, in minor quantities, gas, oil and amber ${ }^{10}$. It is a country politically and economically weak. According to some sources it is a failing country. Apart from that, Ukraine is also corrupt, with a very noncompetitive, indebted economy, without any policy that would guarantee balance in the geopolitical crisis caused by Russia's open aggression towards Ukraine.

After the dissolution of the Soviet Union, the politics of the Russian Federation aimed at acquiring a western legacy, described as norms and values created by the West. At that time, 2 main schools of thought were created: Atlanticism and NeoEurasianism $^{11}$. The forefathers of Atlanticism were: Dimitrij Trenin, Władimir Baranowski, Andrzej Zagorski, Siergiej Karaganow, Aleksiej Rabatow, and Siergiej Rogow $^{12}$. This notion referred to Occidentalism (from XIX century), implying the development of Russia, cooperating directly with the West and highly-developed countries in the world. The implementers of Atlanticism were: Borys Jelcyn, Andriej Kozyriew, (the Ministry of Foreign Affairs) and Jegor Gajdar (Prime Minister). It should be noted that, at that time, Russian's need to subordinate the post-Soviet states, including Ukraine, was not highlighted ${ }^{13}$.

The second school of thought, Neo-Eurasianism, alludes to the notion of Eurasianism from the beginning of XX century. The forefathers of this concept were: Aleksandr Sołżenicyn, Aleksandr Dugin, Eligz Pozdniakow, Natalya Narochnitskaya and Gennady Zyuganov. Another important figure who is considered to be the implementer of this concept is Jewgienij Primakow, who later became the Minister of Foreign Affairs ${ }^{14}$. According to Neo-Eurasianism, Russia is believed to be a special country, joining the traditions of both continents in terms of history, politics, and culture. Russia is neither European, nor Asian, as it constitutes the centre of The Old World. The task of contemporary Russia, which

10 http://www.msz.gov.pl/resource/7b72721f-a820-43a6-a145-39d8fb03c3be [20.08.2016].

11 M. Menkiszak, Rosyjskie wizje postzimnowojennego porzadku międzynarodowego, in:, R. Kuźniar (ed.), Porzadek międzynarodowy u progu u progu XXI wieku, Warsaw 2005, pp. 275-296.

12 A. Legucka, Geopolityczne uwarunkowania i konsekwencje konfliktów zbrojnych na obszarze poradzieckim, Warsaw 2013, p. 69.

13 Ibid., p. 69.

14 Ibid., p. 70. 
has aspirations to become the world power, is to regain and maintain its influence in the post-Soviet area. Aleksandr Dugin singles out two opposite civilisations, which compete with one another in a natural way, aiming at confrontation; these are the Eastern and Western civilisations ${ }^{15}$. His vision concerning the place of Russia in the contemporary world is inspired by the words: "Who rules East Europe commands the Heartland; who rules the Heartland commands the World Island; who rules the World Island commands the World" ${ }^{\prime 16}$.

As a result, the foreign politics of the Russian Federation were directed to objecting to the increasing domination of the USA in the XXI century. Whereas the postSoviet states were "forced" to cooperate with Russia. In 1997, Aleksandr Dubin made the following comment concerning Ukraine: the sovereignty of Ukraine is a negative phenomenon for the geopolitics of Russia and may cause a military conflict. Ukraine, as a sovereign country, with its territorial ambitions, may pose a threat to the whole of Eurasia. Strategically, Ukraine should be a projection of Russia in the South and in the West"17.

The third, and at the same time the newest, concept concerning the foreign politics of the Russian Federation, was started in 1999 by Vladimir Putin. It is called the concept of dynamic balance ${ }^{18}$. In other words it can be recognised under the following names: the concept of pragmatic consensus and multipolar world order ${ }^{19}$. It connects the elements proving the uniqueness of Russia in the world; however, without the element of confrontation with the West. Konstantin Sorokin is regarded as the main precursor. The first time this notion had been officially presented, by Yevgeny Primakov, was at the $51^{\text {st }}$ session of the UN General Assembly. He believed that the world should be multipolar and that Russia should play a key role in it. In such a community, the Russian Federation could be viewed as important, despite being significantly weakened. Its location, close to many

15 Koncepcja neo-eurazjatyzmu Aleksandra Dugina, http://nowyprometeusz.pl/koncepcjaneo-eurazjatyzmu-aleksandra-dugina/ [10.01.2017].

16 P. Eberhardt, Koncepcja Heartlandu Halforda Mackindera, Przegląd Geograficzny, 2011, 2(83), p. 261.

17 A. Legucka, Geopolityczne uwarunkowania i konsekwencje konfliktów zbrojnych...., op. cit., pp. 74-75.

18 Ibid., p.75.

19 K. Gołaś, Rosyjska polityka zagraniczna: koncepcja pragmatycznego konsensusu, http:// geopolityka.net/rosyjska-polityka-zagraniczna-koncepcja-pragmatycznego-konsensusu/ [10.01.2017]. 
important centres of power in the world, would make it possible to support some against others, which, in turn, would put Russia in a strong position, as well as maintain a world order that is beneficial for Russia ${ }^{20}$.

The idea of pragmatic consensus presupposes the achievement of five main aims. Firstly, it would be the renewal of the position of Russia as a main player on the territory of the former Soviet Union. In the future, it also assumes the transformation of the Commonwealth of Independent States in an integrated region of the world, capable of development and maintenance of stability. Secondly, it establishes the usage of the resources attained in the era of the USSR. Thirdly, it is the diversification of contacts with the West. Fourthly, the aims are concerned with increasing cooperation with Asia, mainly China and India. Fifthly, it uses Russia as the country relating Europe with Asia ${ }^{21}$.

In the foreign politics of Russia, different geographical regions concerning partners and rivals can be differentiated. These are the so called circles, the examples of which are: "near abroad" circle, European, continental, global and intercontinental ${ }^{22}$. The countries of "near abroad" are the post-Soviet states. This region is viewed as the place for achieving vested interests. It is also subordinate to the Russian Federation ${ }^{23}$.

Russia, under Vladimir Putin, has never treated the countries of the former USSR as fully independent states. The same applies to Ukraine, Georgia or Moldova. In Russia's strategic assumptions, these countries are treated as states occupying a certain territory, but having Russian identity, a sense of belonging and remaining within its sphere of influence. Alluding to Russia's politics, the factor that may lead to conflict is mainly connected with the lack of acceptance for the power status of Russia in the international arena and the fact that some countries are actively interested in participation in western organisations, such as, for example, the European Union or the North Atlantic Treaty Organization (NATO).

20 A. Bryc, Cele polityki zagranicznej Federacji Rosyjskiej, Toruń 2005, pp. 30-31.

21 A. Legucka, Geopolityczne uwarunkowania i konsekwencje konfliktów zbrojnych..., p. cit., pp. 76-77.

22 A. Bryc, Cele polityki... op. cit.

23 A. Legucka, Geopolityczne uwarunkowania i konsekwencje konfliktów zbrojnych..., op. cit., p. 81. 


\section{The reasons for the conflict in Ukraine}

There are a lot of causes for the outburst of conflict in Ukraine. These are for example: the anocracy of Victor Yanukovych, fully subordinated to Moscow, corruption, nepotism, the economic collapse of Ukraine, social injustice, as well as the case of Julia Tymoshenko, who was about to be acquitted of charges. However, the main reason is connected with Ukraine's active interest in participation in western association structures, such as the European Union.

Ukraine's relations with the European Union started in 1994, since the Partnership and Cooperation Agreement was signed. During the following years, they achieved this within the framework that the European Neighbourhood Policy and Eastern Partnership was expected to establish. Ukraine, in 2009, was invited to join the Eastern Partnership Project within the framework established by the European Neighbourhood Policy ${ }^{24}$.

Poland was also involved in signing the Ukraine-European Union Association Agreement in 2012. In June 2012, the European Parliament decided to send a mission there. The delegation consisted of Pat Cox and Aleksander Kwaśniewski. Despite various objections centred around lies, corruption, blackmail, and the rule of oligarchs in Ukraine, the EU had a positive approach towards this country. "Europe needs Ukraine, considering its demographic potential, its market, millions of Ukrainians employed in EU countries, as well as in Poland. Ukraine is ready to accept our standards, as opposed to Belarus or Russia" ${ }^{25}$.

Contrary to the dreams and full involvement of Ukrainians, on $21^{\text {st }}$ November 2013, a week before the summit of the East Partnership, the contemporary government of Ukraine (under the influence of Moscow) suspended the preparations for signing the Ukraine-European Union Association Agreement. Prime Minister Mykola Azarov, after the president Viktor Yanukovych gave his opinion, announced that Ukraine, in the interest of national security, would not sign this document ${ }^{26}$.

24 https://pl.wikipedia.org/wiki/Stosunki_Ukrainy_z_Unią_Europejską [accessed: 15.01.2017].

25 P. Najsztub, Za Ukrainę!, „Wprost”, 16 (1573), 2013.

26 W. Konończuk, Ukraina rezygnuje z podpisania umowy stowarzyszeniowej $w$ Wilnie: przyczyny i implikacje, https://www.osw.waw.pl/pl/publikacje/analizy/2013-11-27/ukrainarezygnuje-z-podpisania-umowy-stowarzyszeniowej-w-wilnie [accessed: 15.01.2017]. 
The following day at the Maidan, which is the main square in Kiev, where the Orange Revolution in 2004 took place, around 2000 people gathered to protest. It began a bloody strike against taking away the dreams of a better future from the citizens of Ukraine. It was the birth of the so called Euromaidan ${ }^{27}$. The hot spot for Maidan encompassed non-governmental organisations, academic and occidentally-oriented intellectual circles ${ }^{28}$. This is why Euromaidan was called the Revolution of Dignity.

Observing a tense situation in the western part of Ukraine on the night of $21^{\text {st }}$ and $22^{\text {nd }}$ of February 2014, Yanukovych left Kiev and flew to Kharkov. At that time in the Verkhovna Rada of Ukraine, the resolution concerning Tymoshenko's release from prison was passed. Julia Tymoshenko immediately appeared at the Maidan and started to encourage demonstrators in a further struggle. Parallel to these events, the information about the peculiar wealth of Yanukovych went viral in the media. In the opinion of international mass media, Yanukovych received an order to flee from Putin. In a film broadcast by the public TV Russia-1, Putin announced that the aim of this operation was "rescuing the life of the president of Ukraine by a sea route, airfreight and overland" 29 .

Unexpectedly, a vast part of the eastern Ukrainian community, the Russianspeaking one, began to notice the need for sovereignty. Observing the events at the Maidan, this part of Ukraine began to manifest its distinction and independence. The same happened with Crimea.

According to the source literature, Ukraine is divided into 4 main regions: western, central, eastern and southern. The western region consists of: Lviv Oblast, Volhynia Oblast, Rivne Oblast, Ternopil Oblast, Ivano-Frankivsk Oblast, and Chernivtsi Oblast. The central region: Zhytomyr Oblast, Khmelnytskyi Oblast, Chernihiv Oblast, Vinnytsia Oblast, Kiev Oblast, Cherkasy Oblast, Sumy Oblast, Poltava Oblast, and Kirovohrad Oblast. The southern region: Odessa Oblast, Mykolaiv Oblast, Kherson Oblast and the eastern region: Kharkiv Oblast, Dnipropetrovsk Oblast, Luhansk

27 M. Olechawa, Misja Ukraina, Warsaw, 2016.

28 R. Potocki, M. Domagała, D. Miłoszewska, Dekonstrukcja (Euro)Majdanu, [in:] R. Potocki, M. Domagała, D. Miłoszewska (ed.), Czas..., op. cit., pp. 10-36.

29 Крым. Путь на Родину. Аокументальный фильм АнАрея КонАрашова, https://www. youtube.com/watch?v=t42-71RpRgI [accessed: 16.10 .2016 ]. 
Oblast, Donetsk Oblast and Zaporizhia Oblast ${ }^{30}$. From the very beginning of the existence of an independent Ukraine, the national identity was built on totally diverse social attitudes. The sense of belonging to Ukraine was felt mainly by the inhabitants of the western and central regions. "The historic conditioning of the identity of the inhabitants of eastern and southern Ukraine differ. Those terrains, as opposed to the remaining part of modern Ukraine, had never been a part of the Kievan Rus" ${ }^{31}$. The people living there were mostly Russian-speaking. The distinctive feature of this region is the relatively limited popularity of the idea of economic liberalism and liberal democracy, as well as a longing for the days of non-liberal democracy of the Soviet-type and the economic politics of real socialism $^{32}$.

\section{The features of the new war in the Russian-Ukraine conflict}

The Russian-Ukraine conflict is characterised by features of the new dimension of war. The third wave of war is dominated by psychological and informationpropaganda aspects, as well as guerrilla forces and operations led by small, specialised groups of soldiers of special forces.

The psychological aspect is based on manipulating the opponent, "seizure" of part of the territory, arousing and supporting ethnic separatists, creating a regional opposition, aimed at federalisation, leading to the detachment of certain territories from the states. There were some instances of disconnecting a part of a territory from a state to maintain proper relations and cooperation with the Russian Federation. These are: Abkhazia and South Ossetia seceded from Georgia, Transnistria and Gagauzia from Moldavia and Crimea from Ukraine. And when it comes to the notion of supporting local separatists, an example of this can be the

30 J. Konieczna, Ukraina po pomarańczowej rewolucji - co zmieniło się w postawach $i$ wartościach społeczeństwa, Raport OSW, Warsaw, April 2006.

31 R. Lasecki, O co chodzi w konflikcie na Ukrainie, [in:] M. Domagała, R. Potocki (ed.), Formatowanie Ukrainy, II, Warsaw, 2013, pp. 137-138.

32 Ibid., p.139. 
unfinished internal conflict that was started in Donbas and Luhansk in the east of Ukraine ${ }^{33}$.

The propaganda aspect is closely connected with manipulating an opponent and is based on disinformation, which is centred on conveying a multitude of different pieces of information. Moreover, it is not known which of these are true or false, whereas lack of information leads to certain assumptions, causing chaos, uncertainty and fear. Propaganda is one of the assumptions of a hybrid war and the parties of the conflict do not admit openly to the committed acts. Government and military agencies may be provided with false information, data, guidelines, orders and instructions. Any form of activity on the Internet, on the radio, or anywhere else may be used to localise, validate certain information, which, as a consequence, may lead to creating digital topographic maps of the enemy's territory ${ }^{34}$.

Guerrilla warfare involves a small group of combatants, whose aim is to surprise the opponent, whereas the operations conducted by the secret service are characterised by a small group of people, but perfectly trained and prepared to fight with opponents. The actors who are the parties of the conflict in the new dimension of war are very often different groupings, informal ones, such as guerrilla armies, criminal gangs, mercenaries, irregular forces based on clans and other ancestral relations, paramilitary relations, terrorist groupings, military groups, irregular forces of other countries. These groupings are very often financed through plunder, robbery, exaction, kidnapping for ransom, money laundering, illegal commerce etc. ${ }^{35}$.

The hybrid war in Ukraine can be divided into two main kinds of warfare. The first one is the method of conducting war by dint of "seizure", which is the annexation and incorporation of Crimea and the warfare in eastern Ukraine.

33 J.P. Gieorgica, Rosja w Europie i świecie, [in:] A. Dorosz, Z. Olesiński, L. Pastusiak (ed.), Stosunki..., op. cit., p. 290.

34 J. Regina-Zacharski, Wojna na Ukrainie w 2014 roku w świetle wspótczesnych rosyjskich koncepcji polityczno- wojskowych, [in:] R. Potocki, M. Domagała, D. Miłoszewska (ed.), Czas..., op. cit., p. 146.

35 A. Antczak-Barzant, Z. Śliwa, R. Zaniewski, Wojna XXI wieku. Poczatki wojny „trzeciej fali", Warsaw, 2016, pp. 30-31. 
The "price" of Russia's involvement in the process of stabilising the new Ukraine was the annexation of Crimea, which meant the total detachment of Ukraine from the Black Sea and the gaining of a land corridor with Transnistria by Russia. It all started on $27^{\text {th }}$ February 2014, when a group of armed men took over the buildings of the local parliament and government in Simferopol and put some Russian flags there ${ }^{36}$. The official reason for appearance of the Armed Forces of the Russian Federation on the area of Crimea was providing peace on the republic's territory and respecting the right of the citizens of Crimea to national self-determination ${ }^{37}$. On $21^{\text {st }}$ March 2014, in the end, Crimea became under the rule of Russia, as a separate federal subject. The Act of Incorporation was not accepted by the USA, the states of the EU, significant regional powers and obviously Ukraine. Immediately, the voices could have been heard that in such circumstances the Crimean Peninsula had become one of the starting points for conflict on a global scale ${ }^{38}$.

Russian's method to incorporate Crimea was connected with giving promises of help (e.g. financial help) to the native inhabitants of Crimea, higher salaries, pensions, assistance in overcoming addictions etc. It should also be emphasised that after Crimea seceded from Ukraine, the life of Crimeans was supposed to improve significantly. Then, the Russians organised a referendum, the results of which were falsified. The majority of voters were for incorporating Crimea into Russia, which became a pretence to announce the independence of the Republic of Crimea. On the other hand, the peninsula of Crimea is inhabited by 2.4 million people (2001). The majority of the inhabitants, $60.4 \%$, are Russians; the rest are mainly Ukrainians (24.01\%) and Crimean Tatars $(10.21 \%)^{39}$. Despite various opinions, the vast majority of inhabitants of Crimea wanted to secede from Ukraine. The main reasons concerned history, tradition, and their native language, which is Russian.

36 R. Potocki, Krymska wiosna? Myśli (nie) polityczne., [in:] R. Potocki, M. Domagała (ed.), Formatowanie Ukrainy..., op. cit., p.92.

37 Ibid., p. 93.

38 A. Gil , Pótwysep niezgody. Aneksja Krymu przez Federację Rosyjska a bezpieczeństwo regionu czarnomorskiego - uwarunkowania i perspektywy, Rocznik Instytutu Europy Środkowo- Wschodniej, 2014, pp. 145-155.

39 Krym - pótwysep tatarski, ukraiński czy rosyjski, http://www.polskieradio.pl/39/156/ Artykul/1093746, Krym--polwysep-tatarski-ukrainski-czy-rosyjski [accessed: 24.07.2017]. 
The reaction of the Kremlin to Euromaidan included support given to the protesting pro-Russian Ukrainians in the eastern Ukraine. Destabilisation of this region happened very fast. At the very beginning, they took over some administrative institutions in Donetsk and announced the creation of the Donetsk People's Republic (DPR). On $11^{\text {th }}$ May 2014, a referendum took place, and the following day DPR announced its sovereignty. This country is only recognised by the Luhansk People's Republic, Abkhazia and South Ossetia ${ }^{40}$. At the same time, there was a referendum in Luhansk, and on $12^{\text {th }}$ May 2014, the so called Luhansk People's Republic was brought into existence (LPR). On 24 $4^{\text {th }}$ May 2014, the so called Donetsk People's Republic and Luhansk People's Republic signed an agreement on establishing the so called Novorossiya (or New Russia). "It is a form of infringement of Ukrainian constitutional law and, as a consequence, international law, and it also undermines the territorial integrity, sovereignty and independence of Ukraine. It takes place in the conscription process to the illegal separatist armed groupings, threatening the stability and security of Ukraine" ${ }^{\text {. }}$. On the other hand, the inhabitants of eastern Ukraine want to be a part of the Russian Federation. They feel Russias when it comes to identity.

In the middle of April 2014, which was the time when the self-proclaimed, insurgent republics aspired to gaining independence, the Ukrainian forces began an antiterrorist operation (ATO), the aim of which was to regain the buildings taken over by separatists and leading to the dissolution of their armed groupings. After the negotiations held in Geneva, the operation was aborted. It was the time when separatists decided on leading the offensive and took control of the vast majority of cities in Donbas. After Petro Poroshenko was elected president, the operations within ATO were intensified. The Ukrainians managed to regain a few cities, whereas in July separatists withdrew from Sloviansk and Kramatorsk. The successes of the Ukrainian counteroffensive brought a reaction from the Russian Federation, which started to provide separatists with heavy weapons.

40 https://pl.wikipedia.org/wiki/Doniecka_Republika_Ludowa [accessed: 16.10.2016].

41 The decision of the board 2014/499/WPZiB, from 25th July 2014, changing the decision 2014/145/WPZiB concerning the restrictive measures in conjunction with the actions undermining the territorial integrity, sovereignty and independence of Ukraine, or those threatening them (CELEX: 32014D0499). 
Additionally, the regular military units of the Russian Army entered Donbas ${ }^{42}$. What is more, in the middle of August, the Russian Army entered the territory of Ukraine pretending to be a humanitarian aid convoy from the Ministry of Emergency Situations. Russian media kept reporting that this humanitarian help included, for instance: school textbooks for pupils and students, food products, such as groats, flour, tea, canned food or medicaments etc. These were all white trucks (the white convoy) which were borrowed from an anonymous carrier. Kiev brought attention to the fact that the trucks were crossing the borders, where they were not controlled by the Ukrainian authorities. It was also believed that weapons were transported on the trucks.

Military actions in east Ukraine were observed by the whole world. Much effort was directed at finding a peaceful solution. As a result, on $5^{\text {th }}$ September 2014, in Minsk, the members of the so called Trilateral Contact Group (Ukraine, the Russian Federation, OSCE), as well as the representatives of the separatists, signed a protocol on ceasefire in eastern Ukraine ${ }^{43}$. The ceasefire was partially adhered to but another agreement was indispensable. This was the reason why, on $12^{\text {th }}$ February 2015, the leaders of Ukraine, Russia, Germany and France, after a few hours of talks in Minsk, approved of another agreement of the parties concerning the settlement of the conflict in Donbas ${ }^{44}$. In the fighting, Russian soldiers were mixed with the separatists. "The OSCE observers could have had the impression that these were individual volunteers coming from Russian armed forces that fight in Ukraine. For instance, in the Battle of Debaltseve, separatists, mixed with the Russian soldiers from the $5^{\text {th }}$ Armoured Brigade and the $37^{\text {th }}$ Brigade of the Motorised Infantry from Buryatia also took part ${ }^{45}$.

Summing up, Russia's involvement in eastern Ukraine was centred on supporting the Russian-speaking people. Russian's actions were based on sending the so called

42 F. Bryjka, Rosyjska wojna zastępcza w Donbasie, AntePortas - Studia nad Bezpieczeństwem, 1(6), 2016, p. 207.

43 R. Sadowski, A. Wierzbowska-Miazga, Zawieszenie broni na wschodzie Ukrainy, https:// www.osw.waw.pl/pl/publikacje/analizy/2014-09-10/zawieszenie-broni-na-wschodzieukrainy [accessed: 16.10.2016].

44 Sz. Kardaś, W. Konończuk, Mińsk 2 - kruchy rozejm zamiast trwałego pokoju, https://www. osw.waw.pl/pl/publikacje/analizy/2015-02-12/minsk-2-kruchy-rozejm-zamiast-trwalego-pokoju [accessed: 16.10.2016].

45 F. Bryjka, Rosyjska wojna..., op. cit., p. 208. 
"little green men" - the soldiers from the military groups of the Armed Forces of the Russian Federation, wearing unmarked uniforms and driving unmarked tanks. They were "masked" due to an intense propaganda action. The aid of the Russian Federation was based on providing separatists with the necessary military equipment and financial support. Apart from Russia's assistance, factionalists received help from some local oligarchs, members of Yanakovych's family and activists from the Party of Regions ${ }^{46}$. Russia applied an effective tactic in this region, as Russian military units change rotationally in order to deceive an opponent, or, as in Russia's case, in monitoring missions. Russia still maintains the number of 4-5 Heavy Brigades and 2-3 Light Brigades. What is more, there are also 5 regiments of Spetsnaz, military support units, including many different types of artillery and, recently, brigades of Chechens and Ossetians, who are close to the Kremlin. Apart from that, there are also Cossacks from the Don and the Kuban. It is a huge power that, at the right moment, would be able to destroy the Armed Forces of Ukraine, despite the fact that the number of Ukrainian soldiers is 3.5 times higher ${ }^{47}$. In spite of this data, the Kremlin authorities still do not confirm that they support the separatists and are involving their armed forces in these actions. They determine the "little green men" as Russian citizens -volunteers who want to help pro-Russian Ukrainians to regain their independence. What is more, they claim that the Crimea strived to be seceded from Ukraine itself, whereas the white truck convoy was just humanitarian aid from the Kremlin.

\section{Conclusions}

To conclude, the dissolution of the Soviet Union and the creation of 15 new subjects of international relations basically changed the geopolitical situation in this region. The conglomerate of states of various interests, power status

46 W. Konończuk, Ukraina coraz bliżej utraty wschodniej części kraju, http://www.osw. waw.pl/pl/publikacje/analizy/2014-04-16/ukraina-coraz-blizej-utraty-wschodniej-czescikraju [accessed: 08.10.2016].

47 E. Januła, Z Ukraińskiego pola walki, [in:] R. Potocki, M. Domagała, Formatowanie..., op. cit., pp. 130-131. 
and the level of economic and political development began their existence ${ }^{48}$. Countries such as Georgia, Moldavia, or the one described by the author of this paper - Ukraine, target cooperation with the West. They strive to co-participate in such structures as the EU, or NATO. They decide on full liberty, democracy, development, the rule of law, and the pluralism of power.

The protests, which have occurred so far in Ukraine, depicted the various problems of the citizens of Ukraine. However, Euromaidan 2013 was a bit different, as it enabled Ukrainians and international society to understand the problems this country had to deal with. There were a lot of issues that saw the light of day, namely: the omnipresent corruption, the oligarchs growing rich, politics and economy closed for narrow inner circles, underdevelopment, as well as other examples of social injustice. On the one hand, Euromaidan helped to stabilise the situation in west Ukraine, permit presidential and parliamentary elections and the release of political prisoners from jail (e.g. Julia Tymoshenko). On the other hand, it led to war, conflict with the Russian Federation, which has not been settled yet. It aroused the Russian-speaking part of Ukraine to reflect on which side to support. What is more, Euromaidan also contributed to breaking the guarantee of Ukraine's security, assured and signed by Russia in the Budapest Memorandum on Security Assurances.

In the opinion of Ukrainians, Euromaidan and the events related with it is a history of democratic revolution, the Revolution of Dignity aimed at change. Russians, however, view it as a putsch violating political, military and economic relations between Ukraine and Russia for many generations. They believe that their compatriots from the eastern part of Ukraine can only be saved after they secede from Ukraine as a whole. Having a decent job, study prospects and a life in a united Europe are considered to be the Ukrainians' pipe dream. However, in the opinion of the Kremlin, Russia can be the only proponent of the respected and eternal values that join these countries.

48 K. Malak, Wstęp, [in:] A. Legucka, K. Malaka (ed.), Polityka zagraniczna i bezpieczeństwo na obszarze Wspólnoty Niepodlegtych Państw, Warsaw, 2008, p. 5. 
The Russian Federation is a country determined to pursue its goals and consequently achieve its contemporary geostrategy. Hence, the sanctions imposed on Russia by the West pose only a temporary inconvenience, in the opinion of Moscow, and not a reason to stop helping the Russian-speaking people in Ukraine.

\section{Bibliography}

\section{Printed Resources}

Antczak-Barzant A., Śliwa Z., Zaniewski R., Wojna XXI wieku. Poczatki wojny „trzeciej fali", Warsaw, 2016.

Bryc A., Cele polityki zagranicznej Federacji Rosyjskiej, Toruń, 2005.

Bryjka F., Rosyjska wojna zastępcza w Donbasie, AntePortas-Studia nad Bezpieczeństwem, 1(6), 2016.

Clauzewitz C., O wojnie, Warsaw, 2010.

Czaputowicz J., Bezpieczeństwo międzynarodowe. Wspótczesne koncepcje, Warsaw, 2012. The decision of the board 2014/499/WPZiB, from 25th July 2014, changing the decision 2014/145/WPZiB concerning the restrictive measures in conjunction with the actions undermining the territorial integrity, sovereignty and independence of Ukraine, or those threatening them (CELEX: 32014D0499).

Diehl P.F., Goertz G., War and Peace in International Rivalry, Michigan, 2000.

Domagała M., Potocki R. (eds), Formatowanie Ukrainy, II, Warsaw, 2013.

Dorosz A., Olesiński Z., Pastusiak L. (eds), Stosunki międzynarodowe. Teoria i praktyka, Warsaw, 2015.

Eberhardt P., Koncepcja Heartlandu Halforda Mackindera, Przegląd Geograficzny, 2(83), 2011.

Gil A., Pótwysep niezgody. Aneksja Krymu przez Federacje Rosyjska a bezpieczeństwo regionu czarnomorskiego - uwarunkowania i perspektywy, Rocznik Instytutu Europy Środkowo- Wschodniej, 2014.

Konieczna J., Ukraina po pomarańczowej rewolucji - co zmienito się w postawach $i$ wartościach społeczeństwa, Raport OSW, Warsaw, April 2006.

Kuźniar R. (ed.), Porzadek międzynarodowy u progu u progu XXI wieku, Warsaw, 2005.

Legucka A., Geopolityczne uwarunkowania i konsekwencje konfliktów zbrojnych na obszarze poradzieckim, Warsaw, 2013.

Loveman Ch., Assesing the Phenomenon of Proxy Intervention, Conflict, Security and Development, 2(3), 2002.

Lucas E., Nowa Zimna Wojna, Warsaw, 2015.

Malak K., Wstęp, in: A. Legucka, K. Malaka (ed.), Polityka zagraniczna i bezpieczeństwo na obszarze Wspólnoty Niepodległych Państw, Warsaw, 2008. 
Najsztub P., Za Ukrainę!, Wprost, 16 (1573), 2013.

Olechawa M., Misja Ukraina, Warsaw, 2016.

Potocki R., Domagała M., Miłoszewska D. (eds), Czas Euro Majdanu, Warsaw, 2014.

Rasler K., Thompson W. R., Explaining Rivalry Escalation to War: Space, Position, and Contiguity in the Major Power Subsystem, International Studies Quarterly, 3(44), 2000. Stownik terminów z zakresu bezpieczeństwa narodowego, $6^{\text {th }}$ edition, Warsaw, 2008.

Thompson W.R., Principal Rivalries, Journal of Conflict Resolution, 2(39), 1995.

Włodkowska-Bagan A., Rywalizacja mocarstw na obszarze poradzieckim, Warsaw, 2013. Zapałowski A., Bezpieczeństwo Polski w geopolitycznej grze Zachodu z Rosją, Warsaw, 2015.

\section{Internet sources}

Zwiazek Socjalistycznych Republik Sowieckich miałby 90 lat. Rocznica utworzenia, http:// www.newsweek.pl/historia/zwiazek-socjalistycznych-republik-sowieckich-mialby90-lat--rocznica-utworzenia,100002,1,1.html

http://www.msz.gov.pl/resource/7b72721f-a820-43a6-a145-39d8fb03c3be

Koncepcja neo-eurazjatyzmu Aleksandra Dugina, http://nowyprometeusz.pl/koncepcjaneo-eurazjatyzmu-aleksandra-dugina/

K. Gołaś, Rosyjska polityka zagraniczna: koncepcja pragmatycznego konsensusu, http:// geopolityka.net/rosyjska-polityka-zagraniczna-koncepcja-pragmatycznego-konsensusu/

R. Smentek, Alvin i Heidi Toffler: Wojna i antywojna. Jak przetrwać u progu XXI wieku?, http://www.psz.pl/98-ksiazka/alvin-i-heidi-toffler-wojna-i-antywojna-jak-przetrwacu-progu-xxi-wieku

B. Macintyre, Maskirowka - najskuteczniejsza broń Kremla. Wciąż wielu się na nia nabiera, http://www.polskatimes.pl/artykul/3758939,maskirowka-najskuteczniejszabron-kremla-wciaz-wielu-sie-na-nia-nabiera,1,id,t,sa.html

https://pl.wikipedia.org/wiki/Doniecka_Republika_Ludowa

R. Sadowski, A. Wierzbowska-Miazga, Zawieszenie broni na wschodzie Ukrainy, https://www.osw.waw.pl/pl/publikacje/analizy/2014-09-10/zawieszenie-broni-nawschodzie-ukrainy

Sz. Kardaś, W. Konończuk, Mińsk 2 - kruchy rozejm zamiast trwałego pokoju, https:// www.osw.waw.pl/pl/publikacje/analizy/2015-02-12/minsk-2-kruchy-rozejmzamiast-trwalego-pokoju

\section{Film}

Крым. Путь на Родину. Аокументальный фильм Андрея Кондрашова, https://www. youtube.com/watch?v=t42-71RpRgI 